International Journal of Medicine and Pharmaceutical Sciences (IJMPS)

ISSN (P): 2250-0049; ISSN (E): 2321-0095

Vol. 10, Issue 4, Aug 2020, 19-30

(C) TJPRC Pvt. Ltd.

\title{
SIMULTANEOUSESTIMATION AND DEVELOPMENT OF ANALYTICAL METHOD VALIDATION FOR ESTIMATION OF ALLOPURINOL AND ACECLOFENAC IN BULK AND DOSAGE FORMS
}

\author{
ASHISH S MISHRA ${ }^{1 *}$, DEEPALI TOMAR ${ }^{2}$, PEEYUSH KAUSHIK $^{3} \&$ HITESH MALHOTRA $^{4}$ \\ ${ }^{1}$ Faculty of Pharmacy, UPUMS, Saifai, Etawah, Uttar Pradesh, India \\ ${ }^{2}$ Lala Birkha Ram College of Pharmacy, Golpura, Punchkula, Haryana, India \\ ${ }^{3,4}$ Chandigarh College of Pharmacy, Landran, Mohali, Punjab, India
}

\begin{abstract}
This study was conducted with the objectives of performing simultaneous estimation and development of anunpretentious, straightforward, explicit, exact and specific UV spectrophotometric techniqu evalidation for assessment of Aceclofenac and Allopurinol in bulk as well as in dosage form. Various analytical performance parameters such as accuracy, linearity, and precision, limit of detection (LOD) and limit of quantification (LOQ) were resolved by ICH guidelines for method validation. The ideal conditions were established for the investigation or analysis of the drug. The results show that the גmax of the Allopurinol and Aceclofenac were found to be $254 \mathrm{~nm}$ and $275 \mathrm{~nm}$, respectively. The preferred method complies with Beer's law in the concentration range of $4-20 \mu \mathrm{g} / \mathrm{ml}$ and show exceptional sensitivity with linearity. Moreover, the observed limit of detection and limit of quantification were in the range of 2-6 and 6-18 $\mu \mathrm{g} / \mathrm{ml}$, respectively. When the absorbance versus concentration graph was plotted on the calibration curves, a linear relationship was observed with the maximum observed coefficient correlation of 0.9994. The proposed method was interferences free, accurate and simple technique, and it can be widely employed for monotonous quality control analysis.
\end{abstract}

KEYWORDS: Allopurinol, Aceclofenac, Spectroscopy, Precise \& Calibration

Received: Jun 06, 2020; Accepted: Jun 26, 2020; Published: Jul 20, 2020; Paper Id.: IJMPSAUG20202

\section{INTRODUCTION}

Allopurinol is a xanthine oxidase compound inhibitor, with IUPAC named as 1, 5-Dihydro-4H-pyrazolo (3, 4-d) pyrimidin-4-one (figure 1). This is one of the best medications used to diminish urate levels, and is commonly utilized in the treatment of chronic gout. It is normally used to diminish uric acid levels in the blood and urine of individuals with high uric acid levels ${ }^{1}$.

Aceclofenac, which is chemically knownas [(2-\{2,6-dichlorophenyl) amino $\}$ phenylacetooxyacetic acid]is an oral non-steroidal anti-inflammatory drug (NSAID) analog of Diclofenac. It is pharmacologically used as antiinflammatory and as an analgesic, to cure arthritis and spondylitis. It acts fundamentally in the CNS, expanding the torment pain threshold by hinderingboth isoforms of cyclooxygenase, COX-I, COX-II, and COX-III enzymes engaged withsynthesisof prostaglandin. It shows high penetrability to enter into synovial joints, wherein patients with osteoarthritis and related conditions, the loss of articular ligament in the region causes joint pain, tenderness, stiffness, crepitus and local inflammation ${ }^{2-7}$. 
Literature survey reveals few strategies that have been utilized for the quantitative assurance of these two drugs. ${ }^{8-}$ ${ }^{13}$ The goal of the work is to build up a novel yet straightforward UV spectrophotometric strategy for the simultaneous estimation of Allopurinol and Aceclofenac.

\section{METHOD AND MATERIAL}

\subsection{Reagents and Chemicals}

Aceclofenac and Allopurinol of working standard was provided by Jackson pharmaceuticals (p) Ltd, Amritsar, India. All other chemicals used in the analysis were AR grade.

\subsection{Apparatus}

A double beam spectrophotometer systronics (2202-2203) was used for the detection of absorbance; Schimadzu (BL 220 H) weighing balance and $\mathrm{pH}$ meter (Systronics $\mu \mathrm{pH}$ system 361) were used for experimental purpose.

\subsection{Experimental Part}

\subsubsection{Selection of Common Solvent}

After evaluating the solubility of the two drugs in different solvents, $0.1 \mathrm{~N} \mathrm{NaOH}$ has been carefully chosen as common solvent for developing spectral characteristics.

\subsubsection{Determination of Wavelength}

The dilutions of the concentration of $10 \mu \mathrm{g} / \mathrm{ml}$ were obtained for both Allopurinol and Aceclofenac solution. Both the solutions were scanned under UV range (200-400nm) in $10 \mathrm{~mm}$ cell against solvent blank.

\subsubsection{Preparation of Stock Solutions}

\section{Preparation of Stock Solution of Allopurinol}

$10 \mathrm{mg}$ of Allopurinol was precisely weighed into a volumetric flask of $10 \mathrm{ml}$ and dissolved in a very small quantity of $0.1 \mathrm{~N}$ $\mathrm{NaOH}$, the volume was made up with the same. From above standard stock solution, further aliquots of 4, 8, 12, 16, 20 $\mu \mathrm{g}$ $/ \mathrm{ml}$ were prepared. The absorbance was taken using $0.1 \mathrm{~N} \mathrm{HCl}$ and phosphate buffer $(\mathrm{pH} 6.8$ )as blank.

\section{Preparation of Stock Solution of Aceclofenac}

$10 \mathrm{mg}$ of Aceclofenac was weighed correctly and poured in a $10 \mathrm{ml}$ volumetric flask, and then small amount of methanol is added for its dissolution; followed by volume wake up with methanol. From above standard stock solution, further aliquots of 4, 8, 12, 16, $20 \mu \mathrm{g} / \mathrm{ml}$ were prepared. The absorbance was taken using $0.1 \mathrm{~N} \mathrm{HCl}$ and phosphate buffer (pH 6.8) as blank.

\subsubsection{Preparation of Sample Solutions}

Pipette out $10 \mathrm{ml}$ of the stock solution of both Allopurinol and Aceclofenacin two separate volumetric flasks \& then the volume was wakening up with phosphate buffer $(\mathrm{pH}$ 6.5). From the above standard solution, further aliquots were pipette into a volumetric flask $(10 \mathrm{ml})$, and then diluted with sufficient quantity of phosphate buffer (pH 6.5). Blank solutions were also prepared similarly, except for the addition of the drug. Measured the absorbance of Allopurinol and Aceclofenacat 254 and $275 \lambda_{\max } \mathrm{nm}$, respectively.

\subsubsection{Preparation of Calibration Curve}


Different fractions were taken out from both the standard stock solutions, and further diluted with phosphate buffer (pH 6.5) to provide a series of concentration $(8-40 \mu \mathrm{g} / \mathrm{ml})$. The $\lambda_{\max }$ of both the drugs in the phosphate buffer ( $\mathrm{pH}$ 6.5) was observed by UV spectrum, in the range of $200-400 \mathrm{~nm}$. It was found that the peak at $254 \mathrm{~nm}$ (Allopurinol) and 275nm (Aceclofenc) showed maximum absorption, which has been used for further measurements. Absorbance measurement was performed at the determined wavelengths against the phosphate buffer $(\mathrm{pH}$ 6.5) as blank along with $0.1 \mathrm{~N} \mathrm{HCl}$ as co-solvent. By absorbance versus concentration plot, the calibration curves were made.

\subsubsection{Simultaneous Estimation of Allopurinol and Aceclofenac}

\section{Preparation of Stock Solution}

$10 \mathrm{mg}$ of Allopurinol was weighed accurately into a $10 \mathrm{ml}$ of volumetric flask, and dissolved in small quantity of $0.1 \mathrm{~N}$ methanolic $\mathrm{NaOH}$, the volume was made up with $0.1 \mathrm{~N}$ methanolic $\mathrm{NaOH}$. From above standard stock solution, further aliquots were prepared. The absorbance was taken using $0.1 \mathrm{~N} \mathrm{HCl} / \mathrm{pH} 6.8$ phosphate buffer as blank at $\lambda_{1} 254$ and $\lambda_{2} 275$, respectively.

$10 \mathrm{mg}$ of Aceclofenac was weighed accurately into $10 \mathrm{ml}$ of volumetric flask and dissolved in little quantity of $0.1 \mathrm{~N}$ methanolic $\mathrm{NaOH}$, the volume was made up with $0.1 \mathrm{~N}$ methanolic $\mathrm{NaOH}$. From above standard stock solution, further aliquots were prepared. The absorbance was taken using $0.1 \mathrm{~N} \mathrm{HCl} / \mathrm{pH} 6.8$ phosphate buffer as blank at $\lambda_{1} 254$ and $\lambda_{2} 275$, respectively.

\section{Preparation of Mixture of Both the Drugs (Allopurinol and Aceclofenac)}

$10 \mathrm{mg}$ each of mixture (Aceclofenac and Allopurinol) was weighed correctly into a volumetric flask of $10 \mathrm{ml}$ and dissolved in small quantity of $0.1 \mathrm{~N}$ methanolic $\mathrm{NaOH}$, the volume was made up with $0.1 \mathrm{~N}$ methanolic $\mathrm{NaOH}$. From above standard stock solution, further aliquots were prepared. The absorbance was taken using $0.1 \mathrm{~N} \mathrm{HCl} / \mathrm{pH} 6.8$ phosphate buffer as blank at $\lambda_{1} 254$ and $\lambda_{2} 275$, respectively. The readings were taken in triplicate.

The concentration of each component was determined by using simultaneous equation method (Vierodt's method).

$$
\begin{aligned}
& \mathrm{A}_{1}=\mathrm{E}_{1} \mathrm{aC}_{1}+\mathrm{E}_{2} \mathrm{aC}_{2} \text {-------- }\left(\text { at } \lambda_{1}-254 \mathrm{~nm}\right) \\
& \mathrm{A}_{2}=\mathrm{E}_{1} \mathrm{bC}_{1}+\mathrm{E}_{2} \mathrm{bC}_{2}---------\left(\text { at } \lambda_{2}-275 \mathrm{~nm}\right) \\
& \mathrm{A}_{1}=\text { absorbance value of the test solution at } 254 \mathrm{~nm} \\
& \mathrm{~A}_{2}=\text { absorbance value of the test solution at } 275 \mathrm{~nm} \\
& \mathrm{E}_{1} \mathrm{a}=\text { absorptivity of Allopurinol at } 254 \mathrm{~nm} \\
& \mathrm{E}_{1} \mathrm{~b}=\text { absorptivity of Allopurinol at } 275 \mathrm{~nm} \\
& \mathrm{E}_{2} \mathrm{a}=\text { absorptivity of Aceclofenac at } 254 \mathrm{~nm} \\
& \mathrm{E}_{2} \mathrm{~b}=\text { absorptivity of Aceclofenac at } 275 \mathrm{~nm} \\
& \mathrm{C}_{1}=\text { concentration of Allopurinol in } \mu \mathrm{g} / \mathrm{ml} \\
& \mathrm{C}_{2}=\text { concentration of Aceclofenac in } \mu \mathrm{g} / \mathrm{ml}
\end{aligned}
$$

\subsection{Method Validation}


The ICH guideline Q2 (R1) was considered for the validation of the proposed method. Numerous validation parameters for method validation like linearity and range; limit of Detection (LOD) and limit of Quantification (LOQ); Accuracy and Precision; and Robustness were calculated.

\section{Linearity and Range}

Linearity is the potential to produce experimental results that were directly proportional to the analyst concentration, in a specified range. Twenty replicated analyses were performed separately to access linearity, and absorbance versus concentration was plotted to obtain the graph of calibration. The least square regression method was employed for measurement of the linearity. The range of the proposed analytical method was given by the difference between the lower and the upper concentration levels of Allopurinol and Aceclofenac in standard solutions.

\section{Accuracy}

Accuracy is well-defined as the degree of how close the experimental results are, to the true value and the proportion of analyte recovered by performing an assay, from a known concentration of drug. The recovery studies were usually performed to establish the accuracy of the experiment. For which, a standard amount of drug was weighed correctly and transferred into a volumetric flask $(50 \mathrm{ml})$ along with an appropriate amount of $0.1 \mathrm{~N}$ HClfor dissolution, then the volume is wake up with $0.1 \mathrm{~N} \mathrm{HCl}$ to $50 \mathrm{ml}$. The $10 \mathrm{ml}$ of the above solution was pipetted out into another volumetric flask of $100 \mathrm{ml} \&$ the volume was made up of phosphate buffer (pH6.5). From the above standard solution, further aliquots of concentration $24 \mu \mathrm{g} / \mathrm{ml}$ were prepared in a volumetric flask of $10 \mathrm{ml}$. Similarly, the Blank solution was also prepared without the addition of the drug. The absorbance for Allopurinol and Aceclofenac was taken at $\lambda_{\max } 254$ and $275 \mathrm{~nm}$, respectively.

\section{Limit of Detection (LOD) and Limit of Quantification (LOQ)}

The LOD is the minimum concentration of an analyte in a test sample that can be identified, but not quantified. The LOQ is the lowermost concentration of the standard curve that can be calculated with satisfactory accuracy and precision. The LOD and LOQ were estimated by considering the slope of the calibration curve and the standard deviation. The Following equations were used for the calculation;

$$
\mathrm{LOD}=3.3 \sigma / \mathrm{S} ; \mathrm{LOQ}=10 \sigma / \mathrm{S}
$$

\section{Robustness}

The robustness is the ability of an analytical method to remain unaffected by small, but measurable variations in validation parameters of the method and indicates its reliability throughout its normal usage. The robustness was estimated by calculating the impact of minor variations of the most significant variables like

- Change in acid normality $(0.01 \mathrm{~N} \mathrm{HCl}) \&(1 \mathrm{~N} \mathrm{HCl})$

- Change in acid type $\left(0.1 \mathrm{~N} \mathrm{H}_{2} \mathrm{SO}_{4}\right.$ instead of $\left.0.1 \mathrm{~N} \mathrm{HCl}\right)$

$\%$ RSD was determined for concentration for $08 \mu \mathrm{g} / \mathrm{ml}$ at $\mathrm{pH}$ values mentioned above in triplicate.

\section{RESULTS \& DISCUSSIONS}

Simultaneous Estimation of Aceclofenac\& Allopurinol 
The concentration of each component was determined by using simultaneous equation method (Vierodt's method).

$$
\begin{aligned}
& \mathrm{A}_{1}=\mathrm{E}_{1} \mathrm{aC}_{1}+\mathrm{E}_{2} \mathrm{aC}_{2} \text {----------- }\left(\text { at } \lambda_{1}-254 \mathrm{~nm}\right) \\
& \mathrm{A}_{2}=\mathrm{E}_{1} \mathrm{bC}_{1}+\mathrm{E}_{2} \mathrm{bC}_{2} \text {----------- }\left(\text { at } \lambda_{2}-275 \mathrm{~nm}\right)
\end{aligned}
$$

[Table 1: about here]

${ }^{*} \mathrm{C} 1$ and $* \mathrm{C} 2$ were calculated in pH6.8 phosphate buffer \& $\mathrm{C} 1$ and $\mathrm{C} 2$ were calculated in $0.1 \mathrm{~N} \mathrm{HCl}$.

$* \mathbf{C 1}=9.3 \mu \mathrm{g} / \mathrm{ml}, \mathbf{C 1}=9.8 \mu \mathrm{g} / \mathrm{ml}$,

$* \mathbf{C 2}=9.0 \mu \mathrm{g} / \mathrm{ml}, \mathbf{C} 2=9.2 \mu \mathrm{g} / \mathrm{ml}$,

\section{Determination of Wavelength and Calibration Curve}

The study of spectrum revealed that Aceclofenac shows a well-defined $\lambda$ max at $275 \mathrm{~nm}$, whereas Allopurinol shows at $254 \mathrm{~nm}$. These two wavelengths were selected for the development of simultaneous equation. (See figure 2 and 4 for observed peal of $\lambda_{\max }$ and figure 3 and 5 for calibration curves). The optical characteristic parameters are shown in table 1 and 2.

\section{Precision and Accuracy}

The accuracy and precision have been summarized in table 3 and 4along with table 5 and 6 respectively. The Assay percentage was found to be $99.04 \%$. The outcomes of precision (measurements of inter and intraday) and accuracy exhibits excellent reproducibility with the percent relative standard deviation (\%RSD) of less than $2.00 \%$. Therefore, the results indicate that the method is highly precise and accurate.

\section{Precision}

Precision is defined as the degree of repeatability of the method under standard operating conditions. It was estimated for 3 concentration levels $(12,16,20 \mu \mathrm{g} / \mathrm{ml})$ covering the entire linearity range by intermediate (inter-day) as well as repeatability (intra-day) studies and was reported as \% RSD.

\section{Limit of Detection (LOD) and Limit of Quantification (LOQ)}

The LOD and LOQ for Allopurinol in $0.1 \mathrm{~N} \mathrm{HCl}$ were found to be $3.375 \mu \mathrm{g} / \mathrm{ml}$ and $10.22 \mu \mathrm{g} / \mathrm{ml}$ respectively, while the observed values in phosphate buffer is $2.175 \mu \mathrm{g} / \mathrm{ml}$ and $6.59 \mu \mathrm{g} / \mathrm{ml}$, respectively.

In case of Aceclofenac, the LOD and LOQ in $0.1 \mathrm{~N} \mathrm{HCl}$ were obtained to be $6.16 \mu \mathrm{g} / \mathrm{ml}$ and $18.66 \mu \mathrm{g} / \mathrm{ml} \mathrm{respectively}$ while observed values in phosphate buffer is $3.60 \mu \mathrm{g} / \mathrm{ml}$ and $11.16 \mu \mathrm{g} / \mathrm{ml}$ respectively.

\section{Robustness}

Data for robustness has been summarized and tabularized in table 7 and 8

This validation method was carried out, with the objective to provide reliable and accurate method for simultaneous estimation of Allopurinol and Aceclofenac in bulk as well as in formulation. Validation of analytical method defines the documented evidence, which provides the high degree of assurance of results meeting with predetermined specifications and quality attributes. The UV absorption spectrum of the sample $(100 \mu \mathrm{g} / \mathrm{ml})$ was scanned and major peak was obtained at $254 \mathrm{~nm}$ (Allopurinol) and $275 \mathrm{~nm}$ (Aceclofenac) as $\lambda_{\max }$ due to higher absorbance value. The calibration curve indicated the 
coefficient of correlation value of 0.9994 , which indicates linear relationship between concentration and absorbance. The results of accuracy and precision were found to be within limits in accordance with ICH Q2 (R1) guidelines.

Slight deviation was observed during robustness with change in acid composition and change in acid itself RSD slightly exceeded in accordance with, ICH Q2 (R1) guidelines. The sample was found to be stable and all other parameters were well within acceptance level i.e. LOD and LOQ The change in instrument, analyst and duration has not affected the method. The developed UV method was successful in accurate estimation of Allopurinol \& Aceclofenac in formulation.

\section{CONCLUSIONS}

A UV-spectrophotometric method was proposed and validated. The proposed analytical method is easy, economical and experimentally prevents loss of time. Therefore, this will be appropriate for Allopurinol \& Aceclofenac analysis of pharmaceutical formulations in bulk.

\section{REFERENCES}

1. https://medlineplus.gov/druginfo/meds/a682673.html accessed on 4 June 2020.

2. Raza K, Kumar M, Kumar P, Malik R, Sharma G, Kaur M, Katare OP. Topical delivery of aceclofenac: challenges and promises of novel drug delivery systems. BioMed research international. 2014;2014

3. Bushra R, Shoaib MH, Naeem MI, Aslam N. Aceclofenac: a new effective and safe NSAID. International Journal of Drug Delivery Technology. 2013; 4 (1): 34. 2013;42.

4. Drug Bank, 2010. http://www.drugbank.ca/drugs/DB00437. Accessed on 12/08/2010, 11:20 am.

5. Rang, H.P., Dale, M.M., Ritter, J.M., Moore, P.K., 2008. Pharmacology Churchill livinstone. $5^{\text {th }}$ edition. pp. 366.

6. Saraf, S., 2006. Aceclofenac a Potent Non-Stiroidal Anti-Inflammatory Drug. Pharmainfo_net.mht. 19 september 2010

7. Shah, R., Magdum, C., Patil, S, K., Chougule, D.K., Nilofer, N., 2008. Validated spectroscopic method for estimation of aceclofenac from tablet formulation. Res. J. Pharma. Tech. Vol. 1, pp. 430-432.

8. Choudhari VP, Raut RP, Sahoo M, Syal PK, Shinde SN, Hable AA, Kuchekar BS. Development and validation of Stabilityindicating RP-HPLC-PDA method for simultaneous analysis of thiocolchicoside and aceclofenac in pharmaceutical dosage form. J Pharm Res. 2011 Jun; 4(6):1820-3.

9. Sharma S, Akhtar J, Issarani R. Spectrophotometric Method Development for Estimation of Aceclofenac in Phosphate Buffer Dissolution Media. International Journal of Pharmaceutical Quality Assurance. 2010; 2(01):5-8.

10. Nikalje AP, Gadikar R. A simple liquid chromatographic method for simultaneous determination of aceclofenac, methyl salicylate, and benzyl alcohol in pharmaceuticals. Journal of Pharmacy Research. 2018; 12(3):283.

11. Zawilla NH, Mohammad MA, El Kousy NM, Aly SE. Determination of aceclofenac in bulk and pharmaceutical formulations. Journal of pharmaceutical and biomedical analysis. 2002 Jan 1; 27(1-2):243-51.

12. Refat MS, Mohamed GG, Fathi A. Spectrophotometric determination of allopurinol drug in tablets: Spectroscopic characterization of the solid CT complexes. Bulletin of the Korean Chemical Society. 2010; 31(6):1535-42.

13. Pérez-Ruiz T, Martínez-Lozano C, Tomás V, Galera R. Development of a capillary electrophoresis method for the determination of allopurinol and its active metabolite oxypurinol. Journal of Chromatography B. 2003 Dec 25; 798(2):303-8. 

for Estimation of Allopurinol and Aceclofenac in Bulk and Dosage Forms

14. Gupta, Pankaj, and Versha Gupta. "Toxiological Profile of Tetrachloromethane."International Journal of Applied and Natural Sciences (IJANS) 6. 4, Jun - Jul 2017; 79-90

15. Srikanth, P., et al. "Analysis of heavy metals by using atomic absorption spectroscopy from the samples taken around Visakhapatnam." International Journal of Environment, Ecology, Family and Urban Studies 3.1 (2013): 127-132.

16. Harikrishnan, S., and T. J. Bhoopathy. "Vibrational Spectroscopy Investigation and Hybrid Computational (hf \&dft) Analysis on the Structure of Chlorzoxazone." Science and Engineering (IJMMSE) 3.3 (2013): 23-34.

17. Jafri, Hasnain Mehdi, Syeda Beenish Fatima Kazmi, and Muhammad Umer Farooq. "Spectroscopic Diagnostics of High Current Density Exploding Copper Wire Plasma Atstandard Ambient Temperature Pressure."International Journal of Physics and Research (IJPR) 6.2, Apr 2016, 1-8

\section{APPENDIX}

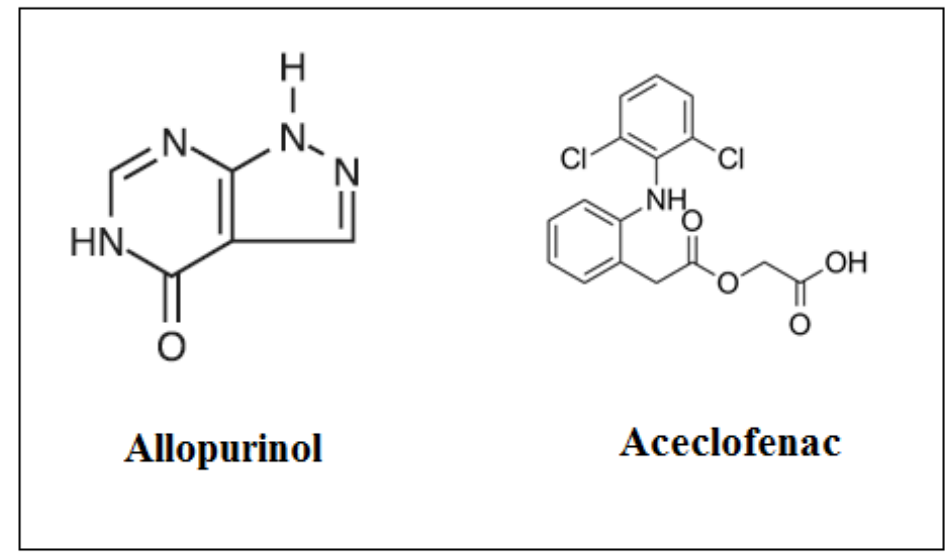

Figure 1: Structure of Allopurinol \& Aceclofenac.

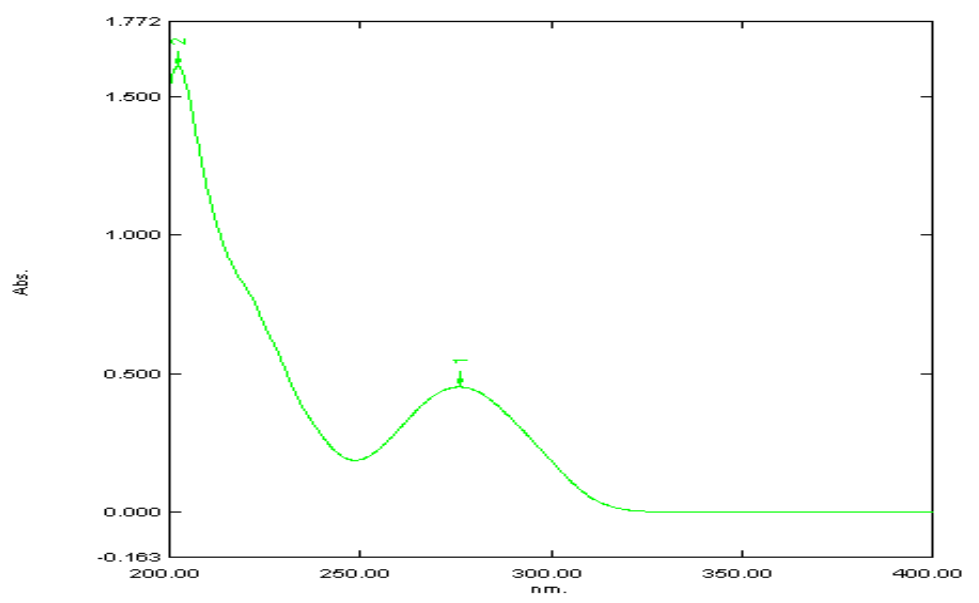

Figure 2: Observed Peak of $\lambda_{\max }$ of Aceclofenac. 


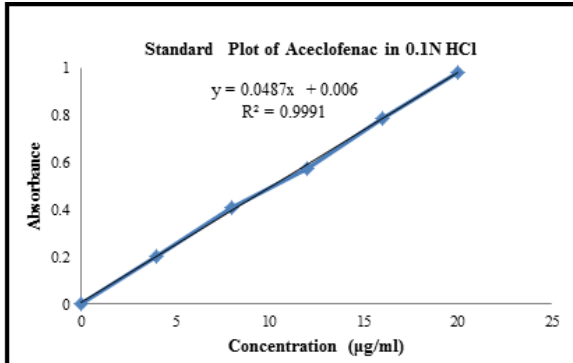

(1)

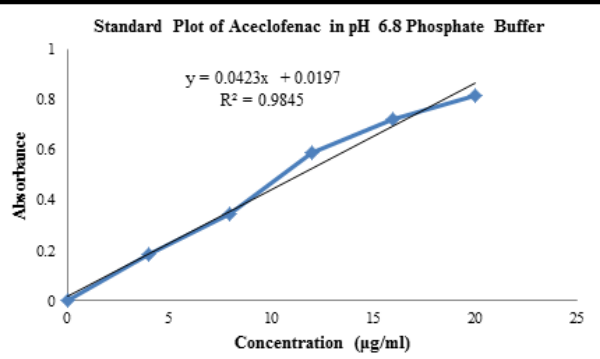

(2)

Calibration Curves of Acelofenac in (1) 0.1N HCl and (2)Phosphate Buffer pH 6.8

Figure 3: Calibration Curves of Aceclofenac.

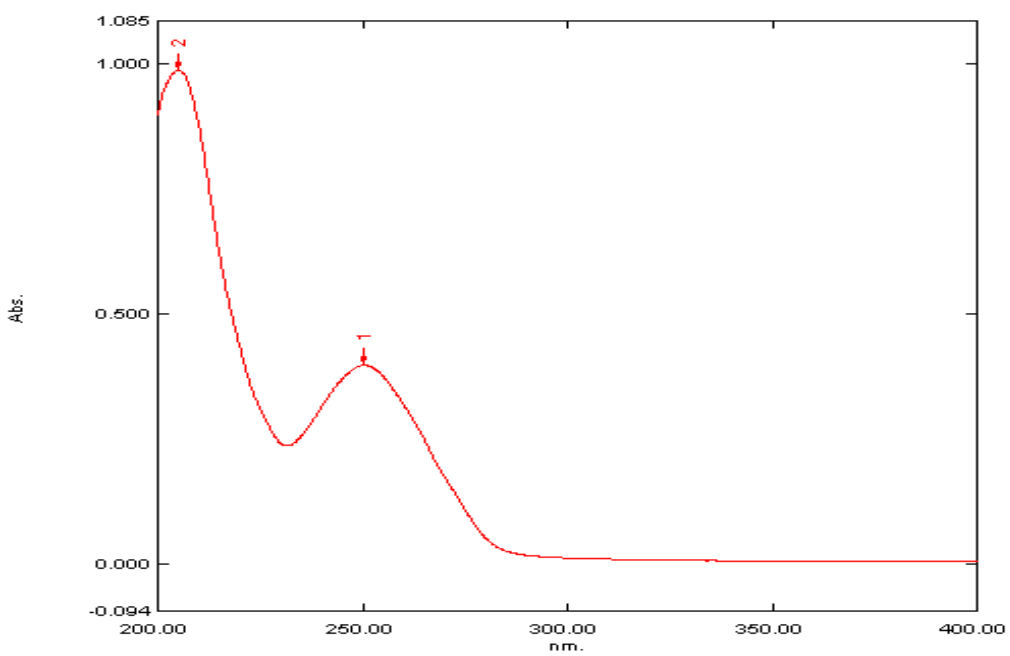

Figure 4: Observed Peak of $\lambda_{\max }$ of Allopurinol.

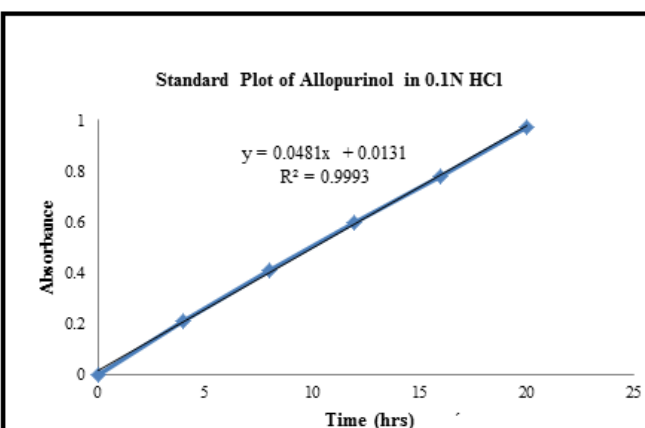

(1)

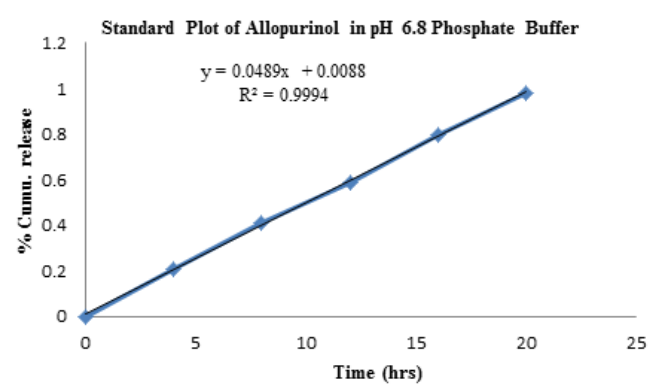

(2)

Calibration Curves of Allopurinol in (1) 0.1N HCl and (2) Phosphate Buffer pH 6.8

Figure 5: Calibration Curves of Allopurinol. 


\section{List of Tables}

Table 1: Absorbance and Absorptivity Values for Simultaneous Estimation of Aceclofenac \& Allopurinol

\begin{tabular}{|c|l|l|c|c|c|c|}
\hline \multirow{2}{*}{ S. No. } & \multicolumn{1}{|c|}{ Drug } & \multicolumn{2}{|c|}{ Dilution } & \multicolumn{2}{c|}{ Parameter } & \multicolumn{2}{c|}{$\begin{array}{c}\text { Absorptivity(a) } \\
\text { Value }\end{array}$} \\
\hline \multirow{2}{*}{1} & \multirow{2}{*}{ Allopurinol } & $0.1 \mathrm{~N} \mathrm{HCl}$ & $\mathrm{E}_{1} \mathrm{a}$ & $\mathrm{E}_{2} \mathrm{a}$ & 0.074 & 0.011 \\
\cline { 3 - 7 } & & $\mathrm{pH6.8}$ phoshphate buffer & $\mathrm{E}_{1} \mathrm{a}$ & $\mathrm{E}_{2} \mathrm{a}$ & 0.030 & 0.094 \\
\hline \multirow{2}{*}{2} & \multirow{2}{*}{ Aceclofenac } & $0.1 \mathrm{~N} \mathrm{HCl}$ & $\mathrm{E}_{1} \mathrm{~b}$ & $\mathrm{E}_{2} \mathrm{~b}$ & 0.003 & 0.044 \\
\cline { 3 - 7 } & & $\mathrm{pH6} .8$ phosphate buffer & $\mathrm{E}_{1} \mathrm{~b}$ & $\mathrm{E}_{2} \mathrm{~b}$ & 0.013 & 0.018 \\
\hline \multirow{2}{*}{3} & \multirow{2}{*}{ Mixture } & $0.1 \mathrm{~N} \mathrm{HCl}$ & $\mathrm{A}_{1}$ & $\mathrm{~A}_{2}$ & 0.790 & 0.472 \\
\cline { 3 - 7 } & & $\mathrm{pH} 6.8$ phosphate buffer & $\mathrm{A}_{1}$ & $\mathrm{~A}_{2}$ & 1.072 & 0.271 \\
\hline \multicolumn{2}{|l|}{ Every value is an average of 3 determinations } \\
\hline
\end{tabular}

Table 2: Optical Characteristic Parameters for Allopurinol in Phosphate Buffer (pH 6.5) and 0.1N HCl

\begin{tabular}{|l|c|c|}
\multicolumn{1}{|c|}{ Parameters for Allopurinol } & $\begin{array}{c}\text { Values } \\
(\mathbf{0 . 1} \text { N HCl) }\end{array}$ & \multicolumn{2}{c|}{$\begin{array}{c}\text { Values } \\
\text { (pH6.5 Phosphate Buffer) }\end{array}$} \\
\hline$\lambda_{\max }(\mathrm{nm})$ & \multicolumn{2}{|c|}{254} \\
\hline Linearity range $(\mu \mathrm{g} / \mathrm{ml})$ & 0.9993 & 0.9994 \\
\hline Correlation coefficient $\left(\mathrm{R}^{2)}\right.$ & 0.0131 & 0.0088 \\
\hline Intercept & 0.0481 & 0.0489 \\
\hline Slope & $\mathrm{Y}=0.481 \mathrm{x}+0.0131$ & $\mathrm{Y}=0.0489 \mathrm{x}+0.0088$ \\
\hline Equation & 3.375 & 2.175 \\
\hline LOD $(\mu \mathrm{g} / \mathrm{ml})$ & 10.22 & 6.59 \\
\hline LOQ $(\mu \mathrm{g} / \mathrm{ml})$ & & \multicolumn{2}{|c|}{} \\
\hline
\end{tabular}

Table 3: Optical Characteristic Parameters for Aceclofenac in Phosphate Buffer (pH 6.5) and 0.1N HCl

\begin{tabular}{|l|c|c|}
\multicolumn{1}{|c|}{ Parameters for Aceclofenac } & $\begin{array}{c}\text { Values } \\
(\mathbf{0 . 1} \text { N HCl) }\end{array}$ & $\begin{array}{c}\text { Values } \\
(\mathbf{p H 6 . 5} \text { Phosphate Buffer })\end{array}$ \\
\hline$\lambda_{\max }(\mathrm{nm})$ & \multicolumn{2}{|c|}{275} \\
\hline Linearity range $(\mu \mathrm{g} / \mathrm{ml})$ & & $4-20$ \\
\hline Correlation coefficient $\left(\mathrm{R}^{2)}\right.$ & 0.9991 & 0.9845 \\
\hline Intercept & 0.006 & 0.0197 \\
\hline Slope & 0.0487 & 0.0423 \\
\hline Equation & $\mathrm{Y}=0.487 \mathrm{x}+0.006$ & $\mathrm{Y}=0.0423 \mathrm{x}+0.0197$ \\
\hline LOD $(\mu \mathrm{g} / \mathrm{ml})$ & 6.16 & 3.60 \\
\hline LOQ $(\mu \mathrm{g} / \mathrm{ml})$ & 18.66 & 11.16 \\
\hline
\end{tabular}

Table 4: Results of Accuracy of Allopurinol

\begin{tabular}{|c|c|c|c|c|c|c|}
\hline \multirow{2}{*}{$\begin{array}{c}\text { Conc. } \\
\text { Taken } \\
(\mathbf{m g})\end{array}$} & $\begin{array}{c}\text { Conc. } \\
\text { Observed } \\
(\mathbf{m g}) \pm \text { SD }\end{array}$ & $\begin{array}{c}\text { Standard } \\
\text { Deviation } \\
(\boldsymbol{\sigma})\end{array}$ & $\begin{array}{c}\text { Relative Standard } \\
\text { Deviation (RSD) }\end{array}$ & $\begin{array}{c}\text { Accuracy in Phosphate Buffer } \\
\text { Observed } \\
(\mathbf{m g}) \pm \text { SD }\end{array}$ & $\begin{array}{c}\text { Standard } \\
\text { Deviation } \\
(\boldsymbol{\sigma})\end{array}$ & $\begin{array}{c}\text { Relative } \\
\text { Standard } \\
\text { Deviation } \\
(\text { RSD) }\end{array}$ \\
\hline 12 & $12.08 \pm 0.007$ & 0.007 & 0.057 & $12.92 \pm 0.008$ & 0.008 & 0.0619 \\
\hline
\end{tabular}

Table 5: Results of Accuracy of Aceclofenac

\begin{tabular}{|c|c|c|c|c|c|c|}
\hline \multirow{2}{*}{$\begin{array}{c}\text { Conc. } \\
\text { Taken } \\
(\mathbf{m g})\end{array}$} & $\begin{array}{c}\text { Conc. } \\
\text { Observed } \\
(\mathbf{m g}) \pm \text { SD }\end{array}$ & $\begin{array}{c}\text { Standard } \\
\text { deviation } \\
(\boldsymbol{\sigma})\end{array}$ & $\begin{array}{c}\text { Relative standard } \\
\text { deviation }(\text { RSD) }\end{array}$ & $\begin{array}{c}\text { Accuracy in Phosphate Buffer (pH6.5) } \\
\text { Observed } \\
(\mathbf{m g}) \pm \text { SD }\end{array}$ & $\begin{array}{c}\text { Standard } \\
\text { deviation } \\
(\boldsymbol{\sigma})\end{array}$ & $\begin{array}{c}\text { Relative } \\
\text { standard } \\
\text { deviation } \\
(\mathbf{R S D})\end{array}$ \\
\hline 12 & $12.23 \pm 0.009$ & 0.009 & 0.073 & $13.00 \pm 0.043$ & 0.043 & 0.330 \\
\hline Each value is an average of three determinants.
\end{tabular}


Table 6: Results of Precision of Allopurinol

\begin{tabular}{|c|c|c|c|c|c|c|}
\hline $\begin{array}{l}\text { Conc. } \\
\text { Taken } \\
(\mu \mathrm{g} / \mathrm{ml})\end{array}$ & Absorbance & $\begin{array}{l}\text { Conc. } \\
\text { Observed } \\
(\mu \mathrm{g} / \mathrm{ml})\end{array}$ & $\begin{array}{c}\text { Standard } \\
\text { Deviation }(\sigma)\end{array}$ & \multicolumn{3}{|c|}{ Relative Standard Deviation (RSD) } \\
\hline 12 & 0.595 & 12.38 & \multirow{3}{*}{0.020} & \multirow{3}{*}{\multicolumn{3}{|c|}{$0.120 \%$}} \\
\hline 16 & 0.781 & 16.75 & & & & \\
\hline 20 & 0.969 & 20.49 & & & & \\
\hline \multicolumn{7}{|c|}{ Intermediate Precision Evening (Day1) } \\
\hline $\begin{array}{l}\text { Conc. } \\
\text { Taken } \\
(\mu \mathrm{g} / \mathrm{ml})\end{array}$ & Absorbance & $\begin{array}{c}\text { Conc. } \\
\text { Observed } \\
(\mu \mathrm{g} / \mathrm{ml})\end{array}$ & $\begin{array}{c}\text { Standard } \\
\text { Deviation }(\sigma)\end{array}$ & $\begin{array}{r}\text { Relative } \\
\text { Deviati }\end{array}$ & $\begin{array}{l}\text { andard } \\
\text { (RSD) }\end{array}$ & $\begin{array}{c}\text { Relative Standard Deviation } \\
\text { between Morning and } \\
\text { Evening }\end{array}$ \\
\hline 12 & 0.602 & 12.62 & \multirow{3}{*}{0.018} & \multirow{3}{*}{\multicolumn{2}{|c|}{$0.109 \%$}} & \multirow{3}{*}{$0.114 \%$} \\
\hline 16 & 0.785 & 16.28 & & & & \\
\hline 20 & 0.973 & 20.48 & & & & \\
\hline \multicolumn{7}{|c|}{ Intermediate Precision Morning Inter Day (Day Ii) } \\
\hline $\begin{array}{l}\text { Conc. } \\
\text { Taken } \\
(\mu \mathrm{g} / \mathrm{ml})\end{array}$ & Absorbance & $\begin{array}{c}\text { Conc. } \\
\text { Observed } \\
(\mu \mathrm{g} / \mathrm{ml})\end{array}$ & \multicolumn{2}{|c|}{ Standard Deviation $(\sigma)$} & \multicolumn{2}{|c|}{ Relative Standard Deviation (RSD) } \\
\hline 12 & 0.603 & 12.74 & \multirow{3}{*}{\multicolumn{2}{|c|}{0.017}} & \multirow{3}{*}{\multicolumn{2}{|c|}{$0.102 \%$}} \\
\hline 16 & 0.785 & 16.55 & & & & \\
\hline 20 & 0.975 & 20.63 & & & & \\
\hline \multicolumn{7}{|c|}{ Intermediate Precision Morning (Day Iii) } \\
\hline $\begin{array}{l}\text { Conc. } \\
\text { Taken } \\
(\mu \mathrm{g} / \mathrm{ml})\end{array}$ & Absorbance & $\begin{array}{c}\text { Conc. } \\
\text { Observed } \\
(\mu \mathrm{g} / \mathrm{ml})\end{array}$ & $\begin{array}{c}\text { Standard } \\
\text { Deviation }(\sigma)\end{array}$ & $\begin{array}{r}\text { Relative } \\
\text { Deviati }\end{array}$ & $\begin{array}{l}\text { andard } \\
\text { (RSD) }\end{array}$ & $\begin{array}{l}\text { Relative Standard Deviation } \\
\text { for the Day I, II, III }\end{array}$ \\
\hline 12 & 0.331 & 16.64 & \multirow{3}{*}{0.04714} & \multirow{3}{*}{\multicolumn{2}{|c|}{$0.29 \%$}} & \multirow{3}{*}{$0.43 \%$} \\
\hline 16 & 0.331 & 16.64 & & & & \\
\hline 20 & 0.332 & 16.69 & & & & \\
\hline
\end{tabular}

Table 7: Results of Precision of Aceclofenac

\begin{tabular}{|c|c|c|c|c|c|c|}
\hline $\begin{array}{l}\text { Conc. } \\
\text { Taken } \\
(\mu g / \mathrm{ml})\end{array}$ & Absorbance & $\begin{array}{c}\text { Conc. } \\
\text { Observed } \\
(\mu \mathrm{g} / \mathrm{ml})\end{array}$ & $\begin{array}{c}\text { Standard } \\
\text { Deviation }(\sigma)\end{array}$ & \multicolumn{3}{|c|}{ Relative Standard Deviation (RSD) } \\
\hline 12 & 0.573 & 12.26 & \multirow{3}{*}{0.030} & \multirow{3}{*}{\multicolumn{3}{|c|}{$0.183 \%$}} \\
\hline 16 & 0.783 & 16.54 & & & & \\
\hline 20 & 0.982 & 20.24 & & & & \\
\hline \multicolumn{7}{|c|}{ Intermediate Precision Evening (Day1) } \\
\hline $\begin{array}{l}\text { Conc. } \\
\text { Taken } \\
(\mu \mathrm{g} / \mathrm{ml})\end{array}$ & Absorbance & $\begin{array}{c}\text { Conc. } \\
\text { Observed } \\
(\mu \mathrm{g} / \mathrm{ml})\end{array}$ & $\begin{array}{c}\text { Standard } \\
\text { Deviation }(\sigma)\end{array}$ & $\begin{array}{r}\text { Relative } \\
\text { Deviati }\end{array}$ & $\begin{array}{l}\text { tandard } \\
\text { (RSD) }\end{array}$ & $\begin{array}{c}\text { Relative Standard } \\
\text { Deviation between Morning } \\
\text { and Evening }\end{array}$ \\
\hline 12 & 0.575 & 12.63 & \multirow{3}{*}{0.028} & \multirow{3}{*}{\multicolumn{2}{|c|}{$0.169 \%$}} & \multirow{3}{*}{$0.176 \%$} \\
\hline 16 & 0.783 & 16.51 & & & & \\
\hline 20 & 0.984 & 20.38 & & & & \\
\hline \multicolumn{7}{|c|}{ Intermediate Precision Morning Inter Day (Day ii) } \\
\hline $\begin{array}{l}\text { Conc. } \\
\text { Taken } \\
(\mu g / \mathrm{ml})\end{array}$ & Absorbance & $\begin{array}{l}\text { Conc. } \\
\text { Observed } \\
(\mu \mathrm{g} / \mathrm{ml})\end{array}$ & \multicolumn{2}{|c|}{ Standard Deviation ( $\sigma)$} & \multicolumn{2}{|c|}{ Relative Standard Deviation (RSD) } \\
\hline 12 & 0.577 & 12.68 & \multirow{3}{*}{\multicolumn{2}{|c|}{0.027}} & \multirow{3}{*}{\multicolumn{2}{|c|}{$0.163 \%$}} \\
\hline 16 & 0.784 & 16.54 & & & & \\
\hline 20 & 0.984 & 20.27 & & & & \\
\hline \multicolumn{7}{|c|}{ Intermediate Precision Morning (Day iii) } \\
\hline $\begin{array}{l}\text { Conc. } \\
\text { Taken } \\
(\mu \mathrm{g} / \mathrm{ml})\end{array}$ & Absorbance & $\begin{array}{c}\text { Conc. } \\
\text { Observed } \\
(\mu \mathrm{g} / \mathrm{ml})\end{array}$ & $\begin{array}{c}\text { Standard } \\
\text { Deviation }(\sigma)\end{array}$ & \multicolumn{2}{|c|}{$\begin{array}{l}\text { Relative Standard } \\
\text { Deviation (RSD) }\end{array}$} & $\begin{array}{c}\text { Relative Standard } \\
\text { Deviation for the Day I, II, } \\
\text { III }\end{array}$ \\
\hline 15 & 0.577 & 12.46 & & & & \\
\hline
\end{tabular}


for Estimation of Allopurinol and Aceclofenac in Bulk and Dosage Forms

\begin{tabular}{|c|c|c|c|c|c|}
\hline 15 & 0.785 & 16.64 & 0.025 & $0.151 \%$ & $0.157 \%$ \\
\hline 15 & 0.986 & 20.35 & & & \\
\hline
\end{tabular}

Table 8: Results of Robustness of Allopurinol

\begin{tabular}{|c|c|c|c|c|c|}
\hline $\begin{array}{c}\text { Conc. Taken } \\
(\mu \mathrm{g} / \mathrm{ml})\end{array}$ & Absorbance & $\begin{array}{c}\text { Conc. } \\
\text { Observed } \\
(\mu \mathrm{g} / \mathrm{ml})\end{array}$ & $\begin{array}{l}\text { Actual Amount } \\
\text { Present in } \mu \mathrm{g} / \mathrm{ml}\end{array}$ & $\begin{array}{c}\text { Standard } \\
\operatorname{Deviation}(\sigma)\end{array}$ & $\begin{array}{l}\text { Relative Standard } \\
\text { Deviation (RSD) }\end{array}$ \\
\hline 08 & 0.523 & 8.60 & \multirow{3}{*}{$08 \mu \mathrm{g} / \mathrm{ml}$} & \multirow{3}{*}{0.007} & \multirow{3}{*}{$0.076 \%$} \\
\hline 08 & 0.453 & 9.53 & & & \\
\hline 08 & 0.399 & 9.23 & & & \\
\hline \multicolumn{6}{|c|}{ Readings for Robustness (0.1n hcl) } \\
\hline $\begin{array}{c}\text { Conc. Taken } \\
(\mu \mathrm{g} / \mathrm{ml})\end{array}$ & Absorbance & $\begin{array}{l}\text { Conc. } \\
\text { Observed } \\
(\mu \mathrm{g} / \mathrm{ml})\end{array}$ & $\begin{array}{c}\text { Actual Amount } \\
\text { Present in } \mu \mathrm{g} / \mathrm{ml}\end{array}$ & $\begin{array}{c}\text { Standard } \\
\text { Deviation }(\sigma)\end{array}$ & $\begin{array}{l}\text { Relative Standard } \\
\text { Deviation (RSD) }\end{array}$ \\
\hline 08 & 0.411 & 7.56 & \multirow{3}{*}{$08 \mu \mathrm{g} / \mathrm{ml}$} & \multirow{3}{*}{$0.006 \%$} & \multirow{3}{*}{$0.072 \%$} \\
\hline 08 & 0.423 & 8.01 & & & \\
\hline 08 & 0.398 & 9.32 & & & \\
\hline \multicolumn{6}{|c|}{ Readings For Robustness (Ph 6.5 Phosphate Buffer) } \\
\hline $\begin{array}{l}\text { Conc. Taken } \\
(\mu \mathrm{g} / \mathrm{ml})\end{array}$ & Absorbance & $\begin{array}{l}\text { Conc. } \\
\text { Observed } \\
(\mu \mathrm{g} / \mathrm{ml})\end{array}$ & $\begin{array}{l}\text { Actual amount } \\
\text { present in } \mu \mathrm{g} / \mathrm{ml}\end{array}$ & $\begin{array}{l}\text { Standard } \\
\text { deviation }(\sigma)\end{array}$ & $\begin{array}{l}\text { Relative standard } \\
\text { deviation (RSD) }\end{array}$ \\
\hline 08 & 0.413 & 7.35 & \multirow{3}{*}{$08 \mu \mathrm{g} / \mathrm{ml}$} & \multirow{3}{*}{0.005} & \multirow{3}{*}{$0.062 \%$} \\
\hline 08 & 0.424 & 7.98 & & & \\
\hline 08 & 0.398 & 8.67 & & & \\
\hline
\end{tabular}

Table 9: Results of Robustness of Aceclofenac

\begin{tabular}{|c|c|c|c|c|c|}
\hline $\begin{array}{c}\text { Conc. Taken } \\
(\mu \mathrm{g} / \mathrm{ml})\end{array}$ & Absorbance & $\begin{array}{c}\text { Conc. } \\
\text { Observed } \\
(\mu \mathrm{g} / \mathrm{ml})\end{array}$ & $\begin{array}{l}\text { Actual Amount } \\
\text { Present in } \mu \mathrm{g} / \mathrm{ml}\end{array}$ & $\begin{array}{c}\text { Standard } \\
\operatorname{Deviation}(\sigma)\end{array}$ & $\begin{array}{c}\text { Relative Standard } \\
\text { Deviation (RSD) }\end{array}$ \\
\hline 08 & 0.412 & 7.54 & \multirow{3}{*}{$08 \mu \mathrm{g} / \mathrm{ml}$} & \multirow{3}{*}{0.006} & \multirow{3}{*}{$0.072 \%$} \\
\hline 08 & 0.423 & 8.03 & & & \\
\hline 08 & 0.418 & 9.32 & & & \\
\hline \multicolumn{6}{|c|}{ Readings for Robustness (0.1n hcl) } \\
\hline $\begin{array}{c}\text { Conc. Taken } \\
(\mu \mathrm{g} / \mathrm{ml})\end{array}$ & Absorbance & $\begin{array}{c}\text { Conc. } \\
\text { Observed } \\
(\mu \mathrm{g} / \mathrm{ml}) \\
\end{array}$ & $\begin{array}{l}\text { Actual Amount } \\
\text { Present in } \mu \mathrm{g} / \mathrm{ml}\end{array}$ & $\begin{array}{c}\text { Standard } \\
\text { Deviation }(\sigma)\end{array}$ & $\begin{array}{c}\text { Relative Standard } \\
\text { Deviation (RSD) }\end{array}$ \\
\hline 08 & 0.410 & 7.84 & \multirow{3}{*}{$08 \mu \mathrm{g} / \mathrm{ml}$} & \multirow{3}{*}{$0.005 \%$} & \multirow{3}{*}{$0.057 \%$} \\
\hline 08 & 0.427 & 8.97 & & & \\
\hline 08 & 0.396 & 9.45 & & & \\
\hline \multicolumn{6}{|c|}{ Readings for Robustness (Ph 6.5 Phosphate Buffer) } \\
\hline $\begin{array}{l}\text { Conc. Taken } \\
(\mu \mathrm{g} / \mathrm{ml})\end{array}$ & Absorbance & $\begin{array}{c}\text { Conc. } \\
\text { Observed } \\
(\mu \mathrm{g} / \mathrm{ml})\end{array}$ & $\begin{array}{l}\text { Actual amount } \\
\text { Presenting } \mu \mathrm{g} / \mathrm{ml}\end{array}$ & $\begin{array}{c}\text { Standard } \\
\text { Deviation }(\sigma)\end{array}$ & $\begin{array}{l}\text { Relative Standard } \\
\text { Deviation (RSD) }\end{array}$ \\
\hline 08 & 0.345 & 8.79 & \multirow{3}{*}{$08 \mu \mathrm{g} / \mathrm{ml}$} & \multirow{3}{*}{0.019} & \multirow{3}{*}{$0.230 \%$} \\
\hline 08 & 0.348 & 7.54 & & & \\
\hline 08 & 0.352 & 8.23 & & & \\
\hline
\end{tabular}


